\title{
Sexualidade e trabalho: estudo sobre a discriminação de homossexuais masculinos no setor bancário*
}

\author{
Agnaldo Garcia** \\ Eloisio Moulin de Souza***
}

SumáRIo: 1. Introdução; 2. Aspectos relacionados aos estudos sobre discriminação; 3. Pesquisas internacionais sobre discriminação de homossexuais no trabalho; 4. Estudos organizacionais brasileiros sobre a homossexualidade; 5 . Caminhos percorridos; 6. Discriminação no trabalho; 7. Conclusões.

Summary: 1 . Introduction; 2 . Aspects related to discrimination studies; 3 . International research on discrimination against homosexuals at the workplace; 4. Brazilian organizational studies on homosexuality; 5 . Trodden paths; 6 . Discrimination at the workplace; 7. Conclusions.

Palavras-chave: discriminação, homossexuais masculinos, banco público, banco privado.

KEY WORDs: discrimination, gay men, public bank, private bank.

Este artigo analisa as possíveis formas de discriminação no local de trabalho direcionadas a funcionários homossexuais masculinos de bancos públicos e privados. Inicialmente são discutidos os conceitos básicos relativos aos estudos sobre discriminação de forma geral e as relações desses conceitos com a discriminação de homossexuais. Com respeito aos aspectos metodológicos, a pesquisa é qualitativa, utilizando um roteiro de entrevista semiestruturado para coleta de dados. Foram entrevistados 10 bancários, trabalhadores de dois bancos públicos federais e de um banco privado com capital inteiramente nacional. Para a análise de dados utilizou-se a análise de

\footnotetext{
* Artigo recebido em jun. 2009 e aceito em set. 2010.

** Doutor em psicologia pela Universidade de São Paulo (USP). Professor do Departamento de Psicologia da Universidade Federal do Espírito Santo (Ufes). Endereço: Av. Fernando Ferrari, 514, Departamento de Psicologia, UFES — Goiabeiras — CEP 29075-910, Vitória, ES, Brasil. E-mail: agnaldo.garcia@uol.com.br.

*** Doutor em psicologia pela Ufes. Professor adjunto do Departamento de Administração da UFES. Endereço: Av. Fernando Ferrari, 514, Departamento de Administração, Ufes — Goiabeiras — CEP 29075-910, Vitória, ES, Brasil. E-mail: eloisiomoulin@gmail.com.
} 
discurso desenvolvida por Michel Foucault. Conclui-se que os entrevistados são alvo de discriminação direta e indireta em razão de sua sexualidade. A discriminação direta manifesta-se na deficiência dos normativos dos bancos públicos estudados em garantir e esclarecer os reais direitos dos trabalhadores homossexuais que têm casamentos homoafetivos, bem como na completa falta de regras que estabeleçam direitos aos homossexuais no banco privado analisado. Contudo, o que mais causa incômodo aos entrevistados são as expressões de discriminação indireta manifestadas no local de trabalho.

\section{Sexuality and work: study on discrimination against gay men in the banking sector}

This article analyzes the possible forms of discrimination against gay employees of public and private banks. Initially we discuss the basic concepts related to studies on discrimination in general and the relationship of these concepts with the discrimination of homosexuals. In regard to the type of research methodology is qualitative, using a script of semi-structured interview for data collection. We interviewed ten works, employees of two federal public banks and a private bank with capital entirely national. For the analysis of data was used the analysis of discourse developed by Michel Foucault. It is concluded that the respondents are targets of direct and indirect discrimination on grounds of their sexuality. Discrimination manifests itself directly in the deficiency of normative public banks studied to ensure and clarify the real rights of workers who have homosexual marriages homoafetivos as well as the complete lack of rules that establish rights for homosexuals in private bank. However, the question that most interviewees are uncomfortable is the indirect discrimination expressed in the workplace.

\section{Introdução}

Na sociedade contemporânea, fronteiras e padrões sociais são cada vez mais contestados e encontram-se cada vez mais fragmentados (Bauman, 1998, 2001; Castells, 1999). Nesse contexto, formas de conduta, com seus valores e práticas, que antes se intentava marginalizar, reduzir e ocultar, de forma a torná-las clandestinas, podem passar a se manifestar e tentar buscar o seu espaço. Grupos anteriormente marginalizados - como mulheres, lésbicas, bissexuais, transexuais e gays - começam a reivindicar seu espaço social em uma tentativa de legitimação (Castells, 1999).

No sistema capitalista de produção o trabalho exerce um papel importante nas relações sociais (Grisci e Bessi, 2004; Schwartz, 1998; Gaska e Frey, 1996), além de atuar como uma das forças constituidoras do próprio homem. $\mathrm{O}$ espaço organizacional apresenta-se como um dos principais locais em que 
se encontram manifestos os dilemas da atualidade, entre eles, a luta pela liberdade e pelo fim da discriminação no trabalho em razão da sexualidade dos membros de uma organização.

A instabilidade do mundo dos negócios, a globalização dos mercados e demais fatores políticos, econômicos e sociais contribuíram para que as organizações caminhassem para outros modelos de gestão que antagonicamente acabaram reafirmando e reconhecendo o modelo burocrático descrito por Weber. Ou seja, de uma forma paradoxal com relação à pós-modernidade, os gestores ainda não conseguiram romper com o modelo burocrático (Brewis, 1996; Dellagnelo; Machado-Da-Silva, 2000) e ainda consideram o espaço organizacional um ambiente neutro, impessoal e desprovido de qualquer singularização.

Embora as relações organizacionais, entre elas as relações interpessoais em uma empresa, tentem romper na contemporaneidade com o modelo burocrático na criação de estruturas hierárquicas mais leves e fluidas, a ideia de um ambiente organizacional neutro, impessoal e despersonalizado ainda é algo defendido pelos gestores das organizações, sendo um valor vivo e marcante nas práticas organizacionais e nas relações interpessoais no trabalho. Contudo, esta impessoalidade e esta neutralidade são mera ilusão, pois o ambiente organizacional é socialmente construído e nele se manifestam todas as formas de relações sociais, como, por exemplo, a sexualidade, o abuso sexual e a amizade (Cortina e Wasti, 2005; Lim e Cortina, 2005; Brewis, 2000a, 2000b, 2001; Brewis et al., 1997, 2000b; Souza e Garcia, 2007).

Este artigo busca contribuir para a discussão que envolve as relações interpessoais no trabalho, através do estudo da relação entre sexualidade e trabalho, analisando mais especificamente como se manifesta no dia a dia a possível discriminação de homossexuais trabalhadores de bancos públicos e privados. Levando-se em conta que as organizações exercem grande influência em nossas vidas hoje, desempenhando talvez o papel do Estado soberano de décadas atrás na tentativa de influenciar e controlar os indivíduos, pode-se observar que toda tentativa de controlar a vida e as expressões relacionadas à sexualidade opera por mecanismos de exclusão dos indivíduos que apresentam comportamentos considerados não desejados.

Para tal, este artigo está organizado da seguinte forma: inicialmente serão apresentadas as principais definições que envolvem discriminação e preconceito. Em seguida são apresentadas pesquisas organizacionais sobre a discriminação de homossexuais no trabalho realizadas no exterior e no Brasil. Posteriormente, são expostas a metodologia, a análise dos dados e as principais conclusões da pesquisa realizada. 


\section{Aspectos relacionados aos estudos sobre discriminação}

As primeiras pesquisas sobre discriminação tinham como principal tema o racismo. Vincent (1996) acredita que o racismo é um fenômeno que se encontra engendrado nas práticas diárias, mas que sua origem está no imaginário das pessoas. Entretanto, este imaginário é mantido e (re)criado por uma série de práticas discursivas que, de acordo com a época e a situação, se constituem por vários mitos.

Na realidade a inquietude em face do racismo e, portanto, a emergência de um discurso teórico sobre este fenômeno, não tem mais do que 40 anos (...). Isto não quer dizer que o racismo não existisse anteriormente (pelo menos algumas formas de racismo), mas que, simplesmente não era revelado. (Vincent, 1996:185)

O discurso racista emergido no século XIX baseou-se em descobertas científicas relacionadas à antropologia física, genética e linguística; entretanto, o discurso atual é sustentado pela biologia e apoiado por alguns sociólogos e historiadores. Assim, a crença em que existem significativas diferenças entre os seres humanos, que existem raças superiores em termos psicológicos, sociais, culturais e espirituais; e que esta superioridade legitima o domínio de uma raça sobre a outra são as principais bases do racismo (Vincent, 1996).

Rios (2007) afirma que o racismo, o antissemitismo, o sexismo e a homofobia são as expressões mais utilizadas e que têm uma relação direta com a discussão sobre preconceito e discriminação nos debates atuais. Entretanto, o autor salienta que, entre todas estas expressões, a discriminação relacionada à homofobia é a menos estudada e discutida, além de ser a mais controversa.

Vale ressaltar que preconceitos são quaisquer formas de "percepções mentais negativas em face de indivíduos e de grupos socialmente inferiorizados, bem como as representações sociais conectadas a tais percepções" (Rios, 2007:27-28). A expressão discriminação significa a "materialização, no plano concreto das relações sociais, de atitudes arbitrárias, comissivas ou omissivas, relacionadas ao preconceito, que produzem violações de direitos dos indivíduos e dos grupos" (Rios, 2007:28). O estudo do preconceito e da discriminação passa a ser um tema mais estudado a partir da II Guerra Mundial e se inicia pelas formas de manifestação do antissemitismo, do racismo e do sexismo. Neste sentido Rios (2007:30) salienta que 
No esforço de compreensão dos fenômenos do preconceito e da discriminação, a cada uma das aludidas manifestações associou-se um conjunto de circunstâncias, na tentativa de explicar a gênese e reprodução destes processos. Nesta empreitada, vislumbrou-se na pertinência cultural e genealógica o traço desencadeador do antissemitismo; na identificação de sinais corporais distintivos, especialmente cor e sinais morfológicos específicos, os marcadores de pertença racial, sob os quais se dinamiza o racismo; pela valorização da distinção morfológica sexual, a atribuição de identidades de gênero binárias, engendrando o sexismo.

Para cada uma destas manifestações (antissemitismo, racismo e sexismo) foram referidas condições específicas para sua produção e reprodução: o antissemitismo foi relacionado ao surgimento de regimes totalitaristas, o racismo foi incorporado aos desdobramentos da escravidão, da cor e de sinais morfológicos. O sexismo foi relacionado à distinção morfológica dos órgãos sexuais, ao binarismo de gêneros e à estrutura familiar patriarcal da sociedade ocidental. Entretanto, só recentemente o preconceito e a discriminação relativos a expressões da sexualidade passaram a ser estudados (Rios, 2007).

Diferentemente do racismo e do sexismo, onde existe a presença de marcadores corporais, ou do antissemitismo, em que a pertinência genealógica pode ser rastreada, a homossexualidade manifesta-se em todas as raças, etnias, sexos e não há como distinguir de forma definitiva um homossexual por meros recursos visuais. A homossexualidade só pode ser colocada como algo "visível" pela autoidentificação ou pela atribuição de terceiros (Rios, 2007). Medeiros (2007) salienta que a visibilidade de negros e mulheres atrai a discriminação, pois não há como ocultar suas condições. Entretanto, quando se fala de homossexuais a ocultação é algo possível ao se fazer "de conta que não é homossexual, isto é, assumindo uma identidade sexual que não é a sua: a identidade heterossexual" (Medeiros, 2007:82).

Além disso, se formos comparar o racismo, o sexismo e o antissemitismo com a discriminação contra homossexuais, existem alguns fatores que atuam como obstáculos no combate à discriminação: (a) diversamente das outras formas de discriminação, pesa sobre a homossexualidade uma condenação moral, uma inaceitabilidade social e política e uma atribuição de relação entre homossexualidade e doença, (b) a homossexualidade tende a afrontar de uma forma mais radical e incômoda as instituições e valores da sociedade (Rios, 2007). Medeiros (2007) enfatiza que em relação aos três espaços sociais onde as pessoas desenvolvem sua vida - familiar, social e profissional -, é no profissional que a discriminação contra homossexuais se torna mais presente. 
Outros aspectos relacionados aos homossexuais, que diferenciam a discriminação sofrida por eles da discriminação racial, é que quando há manifestações sociais e profissionais que envolvem a discriminação de um negro, por exemplo, existe uma solidariedade do meio familiar que não existe na maioria dos casos com os homossexuais. Assim, "os problemas, as dúvidas, os medos e as rejeições [sofridas por um negro] podem ser expostos e vão encontrar, se não a solução, ao menos o conforto do pertencimento" (Medeiros, 2007:82). Entretanto, quando "alguém se vê como homossexual, não vê ao seu lado, na grande maioria das vezes, ninguém 'igual' a ele" (Medeiros, 2007:82). Desde cedo o homossexual incorpora em suas práticas cotidianas a atitude de se calar em relação a sua sexualidade para ser aceito na sociedade e ser excluído do rol de pessoas que são objeto de comentários e xingamentos. Desta forma, o calar-se no âmbito doméstico passa a ser estendido para o nível público (Medeiros, 2007).

Costa (2007) defende que a discriminação de trabalhadores no local de trabalho pode ser direta e indireta. "A discriminação direta pressupõe um tratamento diferenciado proibido. Já na indireta o objetivo discriminador não é explícito" (Costa, 2007:91). Por exemplo, a não concessão e interdição da lei, ao não incluir a possibilidade de união estável entre gays, é uma forma de discriminação direta. Entretanto, as piadas, os comentários inapropriados, a ridicularização e as humilhações praticadas no ambiente de trabalho relacionadas aos homossexuais constituem uma forma de discriminação indireta.

Tendo-se analisado os principais aspectos que envolvem a discriminação em nossa sociedade, faz-se necessário examinar as principais pesquisas encontradas sobre a discriminação de homossexuais circunscritas ao ambiente de trabalho. Portanto, a próxima seção irá discutir os principais estudos sobre discriminação no trabalho sofrida por homossexuais.

\section{Pesquisas internacionais sobre discriminação de homossexuais no trabalho}

Para estudar as possíveis formas de discriminação exercida contra homossexuais no ambiente de trabalho bancário, torna-se necessário entender as relações existentes entre trabalho e discriminação de homossexuais. Com este intuito, os próximos parágrafos objetivam trazer à tona pesquisas internacionais que buscaram discutir questões relacionadas com a discriminação de homossexuais no local de trabalho. Vale salientar que estas pesquisas foram desenvolvidas nos Estados Unidos da América, onde a discussão sobre a temática 
encontra-se em um estágio mais avançado em relação ao Brasil. Entretanto, a seção quatro deste artigo discutirá as pesquisas sobre homossexualidade nas organizações desenvolvidas em solo brasileiro.

Ragins e Cornwell (2001) analisam a discriminação contra empregados que são homossexuais assumidos no trabalho ou apenas percebidos pelos colegas como homossexuais. Eles afirmam que nos Estados Unidos entre 25\% e $66 \%$ de empregados homossexuais fizeram algum registro oficial junto às empresas por terem sido discriminados no trabalho. Contudo, segundo os autores, a maioria dos homossexuais masculinos ou femininos não são assumidos no ambiente de trabalho e isto faz com que o potencial de discriminação deva ser bem mais alto do que os registrados.

A grande preocupação de Ragins e Cornwell (2001) é entender quais os fatores que estão relacionados com a percepção de discriminação no trabalho de lésbicas e gays. Para isso, eles estudam as legislações e normas específicas que protegem os homossexuais, a cultura organizacional e a composição do grupo de trabalho para verificar qual das variáveis tem maior impacto sobre a discriminação no trabalho.

Os autores afirmam que as práticas organizacionais têm um impacto maior na percepção da discriminação de empregados, em razão de sua orientação sexual, do que qualquer outro fator. Embora a existência de legislação proibindo discriminação sexual no trabalho tenha uma importância crítica na redução da discriminação, o fator mais importante para a diminuição da discriminação no trabalho não é a lei, mas exatamente a existência de uma cultura organizacional "amigável" em relação aos homossexuais.

Herek (1998), ao pesquisar trabalhadores americanos que atuam em diversas áreas, afirma que em relação à discriminação e estigmatização de empregados homossexuais há predisposição para dois fatores: (1) empregados homossexuais tendem a esconder sua sexualidade no trabalho e (2) quanto maior a sensação de que há no trabalho discriminação e estigmatização baseada na sexualidade homossexual, mais provável é que os empregados homossexuais escondam sua orientação sexual.

Segundo Hebl e colaboradores (2002), a discriminação no ambiente de trabalho pode ser formal e informal. Embasados nesta crença, estudaram a discriminação formal e informal contra candidatos a emprego estigmatizados ou não como homossexuais em lojas localizadas em shopping centers no estado do Texas. De acordo com os autores, discriminação formal refere-se à discriminação manifestada nas regras da empresa em se contratar e promover o empregado, e discriminação informal é algo mais sutil e envolve os aspectos não verbais e interações verbais. 
Os resultados revelam evidências de que os candidatos a emprego que se apresentavam utilizando um boné com o dizer "Gay Proud" foram estigmatizados e encontraram-se relações interpessoais discriminatórias mais fortes para com eles do que os participantes que usavam um boné com a inscrição "Texan Proud". Entretanto, a análise da discriminação formal não revelou diferenças de tratamento entre os estigmatizados que usavam o boné "Gay Proud" e os não estigmatizados ("Texan Proud"), ou seja, as medidas formais de discriminação não revelaram diferenças de significância entre estigmatizados e não estigmatizados, contudo, tal fato na discriminação interpessoal é evidente (Hebl et al., 2002).

Greenhaus, Parasuraman e Wormley (1990) observam que existem duas formas de comportamento discriminatório no trabalho para com os homossexuais: (a) discriminação no acesso e (b) discriminação no tratamento. A discriminação no acesso faz com que um determinado grupo de pessoas com cargos de comando na organização não permitam que homossexuais sejam contratados para serem funcionários da mesma. A discriminação no tratamento ocorre quando os homossexuais recebem poucas recompensas ou oportunidades de crescimento no trabalho devido a sua condição sexual, tais como não serem indicados para treinamentos, terem poucas ou nenhuma promoção e receberem salários menores. Devido a isso, as formas como os homossexuais gerenciam e revelam sua sexualidade no local de trabalho é uma questão delicada para gays e lésbicas, que sempre passa por uma relação dicotômica entre querer ser visto como heterossexual ou homossexual (Triandis e Gelfand, 1994).

Button (2001) afirma que a autoaceitação de uma pessoa homossexual é cercada por atitudes que tendem a conceber a homossexualidade como algo patológico. Assim, pessoas heterossexuais são vistas como uma referência apropriada para julgar a si mesma e a homossexualidade é vista como algo limitador de suas vidas. Estas atitudes são marcadas com um desejo de ser heterossexual para se assemelhar à cultura predominante. Desta forma, estas atitudes estão fortemente associadas com o surgimento de uma raiva direcionada para uma sociedade homofóbica. Contudo, o nível de percepção de tratamento discriminatório experimentado é algo relativo, pois não se espera que uma experiência discriminatória afete empregados gays e lésbicas da mesma forma ou na mesma extensão.

Herek (1991) afirma que a hostilidade para com pessoas homossexuais tem sido denominada de diversas formas: homofobia, heterossexismo, homossexofobia, homossexismo, homonegativismo, anti-homossexualismo e antihomossexualidade, e o termo mais comumente utilizado na literatura é homo- 
fobia. Contudo, independentemente da nomenclatura utilizada, o preconceito para com os homossexuais é primeiramente uma resposta a um "medo", que é irracional e disfuncional para os indivíduos que manifestam o preconceito, pois os homossexuais são primeiramente vistos por eles como uma aberração individual, e as pessoas que manifestam tal preconceito não veem que, na realidade, esta visão é um reflexo de seus valores culturais (Herek, 1991). Neste trabalho se utilizará os termos homofobia e heterossexismo para caracterizar o preconceito e hostilidade aos homossexuais. Estes termos serão definidos mais adiante.

Muitos homossexuais preferem não revelar sua sexualidade no ambiente de trabalho para evitarem possíveis atos discriminatórios. Assim, os homossexuais "gerenciam" a revelação de sua sexualidade no local de trabalho intentando coibir possíveis discriminações. Preocupados com a questão da revelação da sexualidade, Hebl e Griffith (2002) examinam o processo de autorrevelação no trabalho por pessoas que assumem junto aos seus colegas de trabalho que são gays ou lésbicas. Os autores afirmam que a autorrevelação da sexualidade é uma das questões mais difíceis para os homossexuais porque envolve uma grande energia emocional e um medo de retaliação e rejeição. Entretanto, ao mesmo tempo, aqueles que permanecem no "armário" manifestam baixos níveis psicológicos de bem estar e de satisfação na vida, aumentando os riscos relacionados à saúde, além de gastarem muita energia em atividades focadas em esconder sua homossexualidade, em uma tentativa de evitar qualquer estereotipia e estigmatização.

Embora Yang (1997) afirme que 66\% dos americanos apoiam leis que protegem gays e lésbicas, $62 \%$ de homens gays e $59 \%$ das lésbicas continuam a relatar que sofrem discriminação no trabalho. Assim, apesar da discriminação formal contra homossexuais ser menos frequente nos dias de hoje, a discriminação nos relacionamentos interpessoais no trabalho ainda se sustenta, conforme também afirma a pesquisa feita por Hebl e colaboradores (2002) nos shoppings texanos. Neste sentido, Hebl e Griffith (2002) observam que a discriminação no trabalho ainda existe e atualmente se manifesta de formas mais sutis e não por aspectos formais relacionados às políticas e às normas das empresas.

A presença de discriminação direcionada a homossexuais no local de trabalho colabora com a existência no ambiente laboral do que Meyer (1995) denominou de "estresse de minorias". Meyer (1995) desenvolve o conceito de "estresse de minorias" para explicar o estresse psicológico vivenciado por grupos estigmatizados. Para o autor o estresse de minorias é um estado interveniente entre agentes estressores antecedentes e vivenciados sequencialmente 
em uma cultura sancionada, que categoricamente descreve um determinado grupo com um status inferior, resultante do preconceito e discriminação social. Ou seja, estresse de minoria é o estresse vivenciado por pertencer a um grupo minoritário que é marginalizado e oprimido, podendo provocar uma alienação, uma internalização dos valores sociais negativos e uma atitude negativa relacionada com uma determinada orientação sexual. Assim, para Meyer (1995), o estresse de minorias é operacionalizado por meio de três componentes: homofobia internalizada, estigma percebido e atitudes preconceituosas.

Homofobia internalizada refere-se a uma visão negativa sobre a homossexualidade que tem sido internalizada por gays, lésbicas e bissexuais. O estigma percebido está relacionado com a opinião de que a pessoa será tratada de forma injusta devido à sua sexualidade. Por fim, os eventos preconceituosos são as manifestações direcionadas a homossexuais e bissexuais que são discriminatórias, preconceituosas ou violentas. Os eventos preconceituosos são as ações discriminatórias preconceituosas (Meyer, 1995).

Conforme dito, as pesquisas aqui apresentadas foram desenvolvidas nos EUA, onde o estudo sobre a discriminação de homossexuais encontra-se consolidado no meio acadêmico. A próxima seção irá apresentar as pesquisas sobre a discriminação de homossexuais nas organizações desenvolvidas no Brasil.

\section{Estudos organizacionais brasileiros sobre a homossexualidade}

Pocahy (2007), ao realizar uma pesquisa na parada gay de Porto Alegre em 2004 sobre a discriminação exercida contra homossexuais, concluiu que $32,4 \%$ dos entrevistados sofreram discriminações na escola, $27,8 \%$ nos círculos de amizade e vizinhos, $24,6 \%$ no ambiente familiar e $10,9 \%$ no ambiente de trabalho e agências de emprego. Entretanto, quando o pequisador analisa os processos judiciais que envolvem discriminação de homossexuais, 59\% dos autores dos atos discriminatórios praticaram os atos em situações relacionadas ao mundo do trabalho.

No Brasil, o estudo sobre homossexualidade no ambiente de trabalho ainda é algo incipiente. Somente foram encontrados cinco trabalhos (Siqueira, Ferreira e Zauli-Fellows, 2006; Irigaray, 2007a, 2007b; Ferreira e Siqueira, 2007; Eccel e Flores-Pereira, 2008) que tratam diretamente a homossexualidade nas organizações. Siqueira, Ferreira e Zauli-Fellows (2006) analisam, por meio de uma pesquisa bibliográfica de nove periódicos internacionais no 
período de 1985 a 2005 , a identidade e a cultura gay para se compreender a problemática relacionada à discriminação no trabalho em função da orientação sexual. Os autores salientam a falta de pesquisas organizacionais sobre o tema no Brasil e demonstram que no exterior as pesquisas relacionadas ao homossexualismo nas empresas se dividem em quatro grandes eixos temáticos: discriminação/estigma/homofobia, desenvolvimento de carreira, coming out versus in closeted e igualdade de direitos.

Irigaray (2007a) analisa a política de diversidade implantada no Brasil por uma empresa multinacional do ramo tecnológico, com escritórios no Rio de Janeiro e em São Paulo. O autor inclui em seu estudo de diversidade políticas oficiais da organização focadas para afro-brasileiros, mulheres, homossexuais, deficientes e judeus. Irigaray (2007a) defende que a organização pesquisada tem, na verdade, em sua política de diversidade uma discriminação disfarçada por não existir tratamento em pé de igualdade para as mulheres, os homossexuais, os deficientes e os judeus em relação aos demais funcionários que seguem os ditames sociais considerados "normais" e amplamente aceitos. Além disso, enfatiza que o programa de diversidade implantado no Brasil pela organização, apesar de seguir o modelo utilizado em sua matriz nos EUA, onde obteve sucesso, não consegue atingir seu intento em solo brasileiro por questões culturais e sociais, que constituem processos arraigados de preconceito existentes nos funcionários e no corpo gerencial da empresa, ultrapassando os limites organizacionais e contaminando a política de diversidade promovida pela organização.

As estratégias de sobrevivência de homossexuais no ambiente de trabalho também foram estudadas por Irigaray (2007b). Para tanto, foi feita uma pesquisa com 10 homens que afirmaram ter comportamento homossexual ou bissexual em empresas de médio e grande portes, nacionais e multinacionais. As organizações eram dos setores financeiros, informática e metalurgia. Todas localizadas nas áreas metropolitanas de São Paulo e Rio de Janeiro. Irigaray (2007b) observou que havia três grandes categorias de indivíduos pesquisados: totalmente assumidos, parcialmente assumidos e não assumidos. Para o autor cada categoria utiliza estratégias próprias de sobrevivência no trabalho, o que cria uma identidade homossexual. Os totalmente assumidos adotam as estratégias de gladiadores ou pacificadores. Os parcialmente assumidos são classificados como gente boa ou super homens. Já os não assumidos utilizam três tipos de estratégias: machões, sedutores ou invisíveis.

Quando os assumidos utilizam a estratégia de gladiadores, têm uma posição de enfrentamento, lutando por seus direitos. Como pacificadores buscam evitar qualquer tipo de conflito, sempre sendo simpáticos, bem-humorados, 
não negando ajuda a nenhum colega de trabalho, estando sempre dispostos a cooperar com a equipe (Irigaray, 2007b).

Para Irigaray (2007b), os indivíduos parcialmente assumidos utilizam a estratégia gente boa, muito similar à estratégia de pacificadores utilizada pelos assumidos. Contudo, a estratégia gente boa se diferencia da pacificadora pelo fato de que seu objetivo é desviar a atenção sobre sua sexualidade, enquanto na estratégia pacificadora isto não é um objetivo dos assumidos. Os parcialmente assumidos que utilizam a estratégia de super homem procuram demonstrar total eficiência e dedicação ao trabalho, para esquivarem-se de uma possível discussão sobre sua sexualidade.

Os não assumidos utilizam a estratégia de machão quando tentam evitar contado social com qualquer pessoa que pareça ser gay, tratando estas pessoas de forma pejorativa, bem como evitando assuntos que possam ser relacionados a temas homossexuais, preferindo conversar sobre futebol e mulheres. Na estratégia de sedutor o não assumido enfatiza a todo tempo galanteios às mulheres, valorizando suas constantes aventuras e seus predicados sexuais. Por fim, os não assumidos também utilizam a estratégia de homem invisível, tentando chamar o mínimo de atenção, preferindo ser classificado como tímido (Irigaray, 2007b).

Uma observação sobre o trabalho de Irigaray (2007b) merece destaque. Apesar de o autor afirmar que sua maneira de tratar o tema estaria muito próxima das premissas da pós-modernidade crítica, principalmente pelo fato de possibilitar a recuperação de múltiplas vozes e realidades, a análise feita por Irigaray ainda está presa e bem próxima de categorias que emergiram na modernidade, como, por exemplo, identidade, minoria, heterossexual e homossexual. Contudo, nos dois trabalhos de Irigaray (2007a, 2007b) há um ponto em comum: o autor classifica os homossexuais como uma minoria, aproximando muito o seu trabalho do conceito de estresse de minorias (minority stress) desenvolvido por Meyer (1995).

Ferreira e Siqueira (2007) fazem um estudo com o objetivo e os efeitos de ser gay nas organizações contemporâneas. Assim, pesquisaram quinze gays homens que trabalhavam em empresas públicas, privadas e de economia mista de diversos segmentos de atuação. Salientam que nas políticas de diversidade a parte relacionada aos homossexuais ainda é bastante omissa na maioria das organizações, onde permeia um contexto social bastante conservador, de forma que o ambiente de trabalho não permite que os homossexuais revelem sua sexualidade.

Os autores acreditam que exista uma identidade gay. Esta identidade é desenvolvida pelo processo de estigmatização, onde os similarmente estigma- 
tizados sentem-se mais à vontade entre si, contribuindo com o desenvolvimento de um sentimento de comunidade com tradições e instituições próprias. Além disso, tratam a formação das comunidades gays como um movimento característico de grupos minoritários (Ferreira e Siqueira, 2007).

Segundo Ferreira e Siqueira (2007) o processo de sair ou permanecer no armário e seus efeitos na carreira do indivíduo é algo vital para a análise da homossexualidade no âmbito das organizações. Os pesquisadores defendem que os gays assumidos são mais voltados para a carreira que permita expressar a orientação sexual no trabalho, enquanto os gays enrustidos estão mais focados para escolhas fundamentadas em valores de trabalho mais tradicionais e relacionados a status, compromisso e estabilidade. Desta forma, Ferreira e Siqueira (2007) concluem que os homossexuais assumidos são alvo de ações homofóbicas que criam barreiras para a ascensão profissional e que também dificultam o relacionamento com o restante do grupo.

Para Eccel e Flores-Pereira (2008) não existe nos estudos organizacionais brasileiros um campo para o desenvolvimento dos estudos que envolvem o homossexual, pois os estudos de gênero acabam privilegiando o feminino e os estudos sobre a diversidade se focam na maioria das vezes nas mulheres e pessoas com deficiência. As autoras tratam os homossexuais como pertencentes a uma minoria ao analisarem a política de diversidade voltada para homossexuais em uma livraria.

As pesquisadoras enfatizam que as políticas de diversidade têm um caráter ideológico, mas que se apoiam nos pilares de uma suposta neutralidade e racionalidade técnica de gestão. Elas defendem que as políticas de diversidade não promovem a igualdade por meio da melhoria das condições de trabalho, bem como não aumentam as oportunidades para os grupos discriminados. Assim, Eccel e Flores-Pereira (2008:4) afirmam que a política de diversidade acaba mascarando "as diferenças, pois exclui o seu caráter político, e toma a diversidade como mais um recurso organizacional a ser administrado em busca de melhores resultados (...)". Além disso, concluem que as políticas de diversidade focadas para homossexuais acabam reafirmando e mantendo a hegemonia do que é considerado "normal" (heterossexual) e a desvalorização de tudo que é diferente.

\section{Caminhos percorridos}

Esta pesquisa procurou investigar bancos públicos, aqui denominados de BANCO PÚBLICO A e BANCO PÚBLICO B, e um banco privado, denominado 
de BANCO PRIVADO A. Desta forma, foram entrevistados sujeitos de bancos públicos federais e de banco privado com capital inteiramente brasileiro que serão descritos a seguir. O BANCO PÚBLICO A é uma empresa pública de direito privado, criada pela Lei no 1.083 , de 22 de agosto de 1860, tendo a finalidade de se tornar o "cofre" seguro das classes menos favorecidas. Assim, o BANCO PÚBLICO A tem 148 anos de existência, possui atualmente 2.500 agências bancárias, com aproximadamente 77 mil empregados diretos, mais um grande contingente de pessoas que trabalham em empresas terceirizadas que exercem atividades idênticas às dos demais empregados concursados, como autenticação de documentos e manuseio de valores financeiros, bem como trabalham nas agências sob comando de funcionários concursados devendo aos mesmos subordinação hierárquica. A partir de 1995, a empresa tem implementado diversos programas relativos à reestruturação produtiva do trabalho e apresentou mudanças na área de atuação, buscando competitividade no mercado através da segmentação de clientes. Além de suas agências, o BANCO PÚBLICO A também atua no mercado por meio de suas casas lotéricas, com o intuito de bancarizar as classes sociais de menor renda.

O BANCO PÚBLICO B é o primeiro banco a operar no país, tendo sido fundado em 12 de outubro de 1808 por dom João VI com a vinda da Corte portuguesa para o Brasil. Em 9 de setembro de 1862 foram incorporados ao BANCO B dois outros bancos: o Banco Comercial e Agrícola e o Banco Rural e Hipotecário. Até 1866 o BANCO PÚBLICO B atuava como emissor de moeda. A Lei no 1.349, promulgada em 1866, mudou sua natureza e ele passou a ser um banco hipotecário, ou seja, deixaria de emitir moeda e passaria a ser um banco de depósitos, descontos e operações hipotecárias. Nos dias de hoje, o BANCO PÚBLICO B é uma sociedade de economia mista apresentando uma carteira comercial diversificada. Integram o seu corpo funcional 82.500 empregados, e possui mais de 4 mil agências no Brasil e no exterior.

O BANCO PRIVADO A é uma sociedade anônima inaugurada em 1943 pelo empreendedorismo de seu fundador, sendo uma das maiores instituições privadas bancárias de capital brasileiro em atuação no mercado. Fazem parte do seu corpo funcional 81 mil empregados e o mesmo tem 3.169 agências localizadas no Brasil e no exterior. É considerado uma das instituições bancárias pioneiras na utilização de recursos relacionados à tecnologia da informação no atendimento de seus clientes e no processamento de dados. Apresenta uma carteira comercial altamente diversificada, atuando em diversos segmentos. 
Devido à dificuldade de acesso às instituições financeiras, contatou-se a Diretoria de Bem-Estar Social do Sindicato dos Bancários, que, por meio de sua diretora, indicou sujeitos para serem entrevistados. Além disso, foram contatadas diversas pessoas, empregados ou não de instituições financeiras, bem como associações de bancários e departamentos de recursos humanos de bancos, para indicarem sujeitos que se encaixariam no perfil da pesquisa. Também foram solicitados aos sujeitos entrevistados que indicassem outras pessoas para serem entrevistadas.

A coleta de dados foi o momento mais crucial da pesquisa. A identificação de sujeitos que têm desejos sexuais homoafetivos não é algo fácil, tendo em vista que esse desejo é algo estigmatizado e guardado de modo muito seguro pela maioria das pessoas. Do total de entrevistados, seis informaram que assumiram no ambiente de trabalho sua homossexualidade e quatro sujeitos não.

A maioria das pessoas entrevistadas são de bancos públicos pelo fato de terem maior estabilidade em seus empregos. Elas sabem que não podem ser demitidas pelo fato de serem homossexuais. Já nos bancos privados essa estabilidade não existe e a pessoa pode ser demitida sem justa causa, sem que seja necessário justificar o motivo da demissão, o que levou a maioria das pessoas de bancos privados contatadas a não concederem uma entrevista, pois temiam o risco de uma possível demissão caso fossem identificadas como homossexuais.

Para a coleta de dados foram entrevistados 10 homens que admitiram ser homossexuais. Conforme relatado, os entrevistados em sua maioria eram empregados de bancos públicos, apenas dois entrevistados eram de banco privado. Seis entrevistados pertencem ao BANCO PÚBLICO A, dois ao BANCO PÚBLICO B e dois ao BANCO PRIVADO A. Para manterem os entrevistados anônimos, os mesmos foram denominados com os seguintes nomes gregos: Antístenes, Diógenes, Platão, Sócrates, Xenofonte, Aristóteles, Alcebíades, Plutarco, Ciro e Diocles.

A entrevista foi baseada em um roteiro semiestruturado. Desta forma, diante das respostas fornecidas pelos funcionários, o pesquisador pôde modificar o roteiro previamente traçado, com o intuito de obter informações e dados mais confiáveis e informações julgadas necessárias para a realização da pesquisa. Posteriormente, as entrevistas foram transcritas e para considerá-las utilizou-se a análise do discurso.

A análise do discurso é algo múltiplo e heterogêneo, assim, existem diversas "análises" do discurso. Diante desta constatação, este trabalho utiliza a desenvolvida por Foucault $(1999,2002,2003)$. A próxima sessão trará alguns conceitos e explicações sobre isso. 


\section{Algumas considerações sobre a análise do discurso foucaultiana}

De uma forma geral pode-se afirmar que Foucault acredita que o discurso constitui o mundo social e é constituído por ele. No entanto, Foucault rompe com a posição antropológica tradicional de sujeito, exatamente por acreditar que a antropologia tradicional está diretamente relacionada ao humanismo e que, devido a isso, cria um conceito transcendental de sujeito. Foucault não enxerga o discurso e o próprio homem como algo pronto, acabado, fixo e estático, nem como possuidor de uma essência. Então, o que seria a análise do discurso para Foucault? Sobre a análise do discurso Foucault (1996:17-19) afirma que:

Não é uma teoria na medida, por exemplo, em que eu não sistematizei as relações entre as formações discursivas e as formações sociais e econômicas, cuja importância foi estabelecida pelo marxismo de uma forma incontestável. Essas relações foram deixadas de sombra. Seria preciso elaborar tais relações para construir uma teoria. (...) Poderíamos perguntar então o que é a Archéologie, se não é nem uma teoria nem uma metodologia. Minha resposta é que é alguma coisa como a designação de um objeto: uma tentativa de identificar o nível no qual precisava situar-me para fazer surgir esses objetos que eu tinha manipulado durante muito tempo sem saber sequer que eles existiam, e, portanto, sem poder nomeá-los. (...) Foi esse ponto de vista que tentei definir na Archéologie du Savoir. Trata-se, em suma, de definir o nível particular ao qual o analista deve colocar-se para fazer aparecer a existência do discurso científico e seu funcionamento na sociedade.

Em relação à análise do discurso presente na arqueologia, não há um terreno sólido e único do que seria o discurso, mas sim um terreno movediço, onde se podem verificar três formas de análise do discurso: um discurso totalmente dependente das práticas extradiscursivas (práticas sociais); a colocação entre parênteses dessas práticas extradiscursivas para concentrar a descrição no plano exclusivo do discurso; a incorporação, enfim, dessas práticas extradiscursivas à análise, seguindo um método rigoroso, mas ainda dando importância maior ao pré-discursivo do que às práticas sociais (extradiscursivas) (Foucault, 1996).

Entretanto, o principal intento de Foucault é caminhar em direção a uma análise pós-estruturalista do discurso. É na genealogia que Foucault vai libertar-se das ambiguidades arqueológicas e criar um conceito pós-estruturalista de discurso. Na tentativa de solucionar os problemas e ambiguidades na 
análise do discurso apresentada nos três movimentos da arqueologia, Foucault irá em direção à genealogia. Para entender melhor o que é a genealogia e suas implicações na análise do discurso, temos de entender qual é, para Foucault, o papel do sujeito na produção de um discurso.

Como Foucault (1996:30-31) mesmo afirma, o importante em uma análise do discurso é "saber quais as condições impostas a um sujeito qualquer para que ele possa se introduzir, funcionar, servir de nó na rede sistemática do que nos rodeia". Foucault não acredita em um sujeito cognoscente e autônomo, consequentemente, não acredita em um sujeito criador de discurso. Levando-se em consideração esse raciocínio, a análise do discurso não tem como objetivo e ponto central a análise que partiria do sujeito para explicar suas relações com o mundo externo. A análise do discurso pretende investigar a existência de certos objetos que se desenvolvem, funcionam e se modificam sem nenhuma referência a algo considerado intuitivo e fundamentado em um sujeito. Os sujeitos se limitam a entrar na análise do discurso, "por portas por assim dizer laterais, no interior de um sistema, que não somente se conserva desde certo tempo, com sua sistematicidade própria e em certo sentido independente da consciência dos homens" (Foucault, 1996:30). Destarte, o discurso tem existência própria, sendo independente da existência desse ou daquele sujeito.

Baseando-se nesses princípios, Foucault (2003) irá analisar o discurso seguindo dois conjuntos. O primeiro conjunto, denominado pelo autor de crítico, coloca em prática o princípio da inversão, caracterizando-se por buscar formas de exclusão, limitação, apropriação do discurso, ou seja, analisar por que interesses e necessidades se formam os discursos, como se modificam e se deslocam e que força esse discurso exerce. O segundo conjunto, denominado por Foucault de conjunto genealógico, tem o intento de pôr em prática os princípios presentes no conjunto crítico: "como se formaram, através, apesar, ou com o apoio desses sistemas de coerção, séries de discursos; qual foi a norma específica de cada uma e quais foram suas condições de aparição, de crescimento, de variação" (Foucault, 2003:60-61).

Em Foucault $(1999,2002)$, o discurso é uma construção social envolta por relações de poder. Para Foucault (2002), quando um sujeito fala, quem fala é a história, pois todo discurso está diretamente relacionado com a construção social e histórica do homem. Portanto, quando se analisa o discurso sob essa ótica, o que se está realmente analisando são as relações de poder historicamente situadas, pois o sujeito que fala não é visto como um ser autônomo. 


\section{Discriminação no trabalho}

Depois de analisar os discursos de 10 trabalhadores (três deles não possuem nível superior) com idades entre 23 e 55 anos - a maioria concentra-se na faixa etária dos 45 anos - , que apresentam tempo de trabalho em serviço bancário oscilando entre seis meses e 34 anos - boa parte tem entre 20 e 30 anos de trabalho bancário - , resta fazer a análise dos dados coletados.

Em relação à discriminação sofrida nos bancos pelos pesquisados, podese afirmar que ocorrem discriminações diretas e indiretas. Em relação à discriminação direta, deve-se esclarecer que tanto o BANCO PÚBLICO A quanto o B concedem de forma explícita plano de saúde para os companheiro(a)s dos funcionários que têm relações homoafetivas. Apesar de concederem tal benefício, estes bancos manifestam discriminação direta pela falta de clareza das normas que regulam estes procedimentos, bem como pela não extensão de outros benefícios aos casais homossexuais. No banco privado analisado a discriminação direta é mais forte que nos bancos públicos, pois nele não existe nenhuma norma que conceda qualquer tipo de benefício para pessoas que possuam relações homoafetivas estáveis.

Contudo, o que parece incomodar mais aos entrevistados são as discriminações indiretas. A discriminação indireta é algo comum no ambiente de trabalho em todos os bancos estudados, apesar de serem proibidas pelos seus códigos de ética. Elas se manifestam de diversas formas; contudo, uma delas aparece em todas as falas dos entrevistados: as piadas que tratam os homossexuais de forma caricata e pejorativa.

Sendo a presença destas piadas uma unanimidade entre os entrevistados, quais seriam as outras formas percebidas relacionadas à discriminação indireta de acordo com a análise individual da fala de cada pesquisado? Assim, os relatos abaixo visam enfatizar outras formas de discriminações indiretas manifestadas pelos entrevistados, mesmo que não sejam unânimes entre eles.

Antístenes só recebeu sua primeira promoção 14 anos após sua contratação no banco e tornou-se gerente com 19 anos de carreira. Ele afirma claramente que, apesar de trabalhar em banco público que permite a inclusão de dependentes oriundos de relações homoafetivas no plano de saúde, a sexualidade influenciou e contribuiu muito na demora em ser promovido. Atribui à exclusão de homossexuais do convívio social em lugares informais, como bares e jogos de futebol, a dificuldade de se formar redes de relacionamentos que permitam crescer na empresa. Apesar de a empresa onde Antístenes trabalha ter critérios explícitos sobre a seleção do corpo gerencial, fazendo parte 
das etapas de seleção de um gerente a avaliação de currículo, as provas de conhecimento e o curso de formação, o processo não é totalmente isento.

Ser aprovado no processo seletivo apenas inclui o candidato em um banco de habilitados para o exercício do cargo gerencial. A pessoa só é empossada no cargo por meio de outra etapa seletiva realizada entre os nomes que estão neste banco de habilitados, processo este composto principalmente por uma entrevista realizada por uma banca formada pelos membros do alto escalão da empresa. Exatamente nesta etapa existe margem de manipulação por critérios puramente subjetivos que não precisam ser justificados para o candidato que for considerado reprovado.

Assim, uma ótima classificação no banco de habilitados não garante que uma pessoa com classificação inferior seja a escolhida pelo alto escalão da empresa, ou seja, o relacionamento próximo com pessoas da direção dá ao candidato uma grande vantagem em relação aos demais, mesmo que ele seja o último classificado no banco de habilitados. É neste contexto que Antístenes declara que a homossexualidade afetou o seu crescimento, exatamente pela dificuldade de adentrar e fazer parte das atividades informais realizadas em conjunto com os membros do alto escalão da empresa, o que lhe permitiria uma maior proximidade com os mesmos.

Diógenes afirma que a ridicularizarão de homossexuais pelo corpo gerencial é algo corriqueiro e que basta o homossexual não estar no recinto para ser o alvo de chacotas destinadas especificamente a ele. $O$ interessante é que Diógenes acredita que este fato não aconteça em relação ele, pois se considera uma pessoa discreta, apesar de muitos membros do corpo gerencial saberem sobre sua homoafetividade. Aliás, os entrevistados, com exceção apenas de Alcebíades, Xenofonte e Aristóteles, evitam relatar um fato concreto de discriminação sofrida por eles, mas tendem a relatar, a enfatizar e a salientar somente as discriminações sofridas por terceiros. Assim, por exemplo, Diógenes acredita que não é alvo das ridicularizações destinadas aos homossexuais da empresa. Resta saber o que o corpo gerencial fala sobre ele quando não está presente. Neste sentido, Platão também afirma que não é discriminado, mas que colegas de trabalho discriminam outros homossexuais que trabalham no banco, inclusive vigilantes e clientes que sejam classificados como homossexuais.

Da mesma forma que Antístenes, Diógenes também demorou 20 anos para ganhar sua primeira função de confiança e somente com 22 anos de carreira conseguiu ser gerente. Aliás, com 34 anos de empresa, até hoje Xenofonte é escriturário e não conseguiu ocupar de forma definitiva alguma função de confiança, apesar de ter vivenciado algumas experiências rápidas como comis- 
sionado. Sobre este fato Xenofonte relata que foi preterido em uma escolha para ocupar um cargo gerencial e demonstra uma grande mágoa em relação ao ocorrido, pois desconfia que a sua sexualidade seja o principal motivo por não ter sido o escolhido.

Sócrates é destinado a trabalhar de forma isolada, como se estivesse em quarentena de alguma doença, sem nenhum contado com os clientes do banco e pouco contato com os demais funcionários. Trabalha oito horas por dia dentro de um arquivo que apresenta péssimas condições de trabalho, com equipamentos obsoletos, móveis velhos e conservação física do local a desejar. Aliás, Sócrates nunca conseguiu ocupar qualquer função de confiança no banco, onde trabalha há 25 anos. De forma semelhante ao relatado por Diógenes, Sócrates afirma que os funcionários da central onde trabalha não o tratam com discriminação, mas tratam com discriminação os outros homossexuais que trabalham ali por meio de brincadeiras sobre a forma de eles andarem, falarem e desmunhecarem a mão.

Aristóteles teve dificuldades de crescer na carreira. Quando conseguiu ocupar uma função gerencial, foi vítima de um fato, denominado pelo mesmo de "A trama". "A trama" ocorreu por meio da abertura de um processo administrativo que Aristóteles sofreu. Ele acredita que foi um plano elaborado pelo corpo gerencial para the retirar a função por ser homossexual. Isto é comprovado pelo fato de que, mesmo o processo administrativo tendo absolvido Aristóteles, ele foi punido com a perda da função gerencial e hoje é apenas escriturário, que é o cargo mais baixo que uma pessoa pode ocupar no banco, apesar de ter 21 anos de carreira.

Semelhantemente a Antístenes, Aristóteles informou que o banco onde trabalha é repleto de grupinhos e panelinhas. Quem não faz parte destes grupos frequentados por pessoas aparentemente heterossexuais é discriminado e não consegue crescer na carreira. Além disso, destaca que os homossexuais não são incluídos nestes grupos porque seus membros acham que os homossexuais prejudicam a imagem do banco.

Alcebíades relata que foi discriminado de forma violenta recentemente por outro funcionário do banco. Apesar de ser gerente, Alcebíades sofreu uma tentativa de ridicularização por parte de um funcionário também comissionado, mas que ocupa posição inferior à sua na hierarquia da empresa. Este funcionário discutiu com Alcebíades sobre a forma de execução de uma tarefa no banco, ficou bastante nervoso e passou a chamar Alcebíades de "mocinha" para, assim, intimidá-lo. Foi aberto um processo administrativo contra o funcionário, que foi absolvido. Alcebíades recorreu da decisão sobre o processo administrativo e novamente perdeu. Por incrível que pareça, 
apesar de o código de ética do banco proibir qualquer forma de tratamento discriminatório entre os empregados, o funcionário não levou sequer uma advertência pelo seu comportamento. Tudo foi abafado por panos quentes. Vale ressaltar que Alcebíades demorou 13 anos para conseguir ocupar função de confiança no banco.

Ciro acredita que não há discriminação na empresa onde trabalha. Contudo, se assim fosse, por que ele criou vários mecanismos de defesa para proteger-se em relação à sua homoafetividade no local de trabalho? Isto por si só demonstra que Ciro sente seu local de trabalho como um local hostil para os homossexuais. Entretanto, ao falar sobre terceiros, deixa claro que eles são discriminados no trabalho por meio de xingamentos (veadinho) e brincadeiras pejorativas.

Plutarco, apesar de ser visto como uma pessoa competente pelos seus superiores, não conseguiu ser promovido para cargos gerenciais, tendo inclusive sido avisado que isto nunca ocorreria, pois o corpo gerencial havia feito um pacto para que ele não ocupasse um lugar na gerência do banco. Ainda afirmou que as pessoas só veem o homossexual como uma máquina de fazer sexo, enfatizando apenas aspectos relacionados à sexualidade e nada mais. Plutarco nunca declarou para os colegas de trabalho que é homossexual e acredita que, se assim o fizesse, seria demitido.

Diocles e Plutarco deixam claro que um homossexual afeminado teria poucas chances de contratação no banco privado em que trabalham, apesar de o mesmo não ter nenhuma norma escrita que proíba a contratação de pessoas afeminadas. Outro fator direcionado aos homossexuais afeminados é que, caso consigam passar pela fase de contratação, sua promoção não irá acontecer com tanta facilidade, pois as mesmas ocorrem por indicação do corpo gerencial, que tem preconceito contra homossexuais.

\section{Conclusões}

Há evidências claras de existência de discriminação direta e indireta em todos os bancos estudados (Costa, 2007). A discriminação direta é mais forte no BANCO PRIVADO A do que nos dois bancos públicos analisados. Contudo, isto não significa que os bancos públicos estejam isentos e purificados da presença de formas de discriminação direta. Entretanto, observou-se que o que mais incomoda aos trabalhadores são as manifestações de discriminações indiretas.

A discriminação indireta se apresenta no dia a dia do ambiente de trabalho das seguintes maneiras: (a) piadas que falam pejorativamente de for- 
ma generalizada sobre homossexuais, (b) isolamento para que não tenham contato com clientes e até mesmo com demais funcionários, (c) condições de trabalho inferiores às ofertadas para os demais empregados, (d) exclusão de participação nos grupos informais e atividades ocorridas fora da empresa, (e) brincadeiras, fofocas e ironias sobre as formas de andarem, falarem e gesticularem quando não estão presentes no recinto, (f) xingamento relacionado à evidenciação de uma suposta feminilidade pertencente a homossexuais ("mocinha", "veadinho"), (g) dificuldades de crescimento na carreira e (h) dificuldade de contratação de homossexuais, principalmente afeminados, por gerentes de bancos privados.

Trabalhar com discriminação não é um tema fácil. Requer muita habilidade e tato na condução da pesquisa. Diante de todos os fatos expostos acredita-se que o fim da discriminação relacionada a gays depende muito de mudanças nos valores culturais e filosóficos relacionados à concepção de mundo e consequentemente da sexualidade dos seres humanos.

A superação da discriminação e da homofobia acontece no nível discursivo quando ocorrer a superação e desconstrução da homossexualidade e da heterossexualidade como identidades sexuais (Rios, 2007; Louro, 2004; Swain, 2001). Em outras palavras, enquanto o uso de tais termos existirem sempre haverá discriminação. Entretanto, a questão é mais complexa do que apenas uma mudança de palavras, pois não basta apenas mudar-se os termos empregados para que ocorra automaticamente o fim da discriminação e da homofobia. O que deve ser mudado são os valores culturais e filosóficos que criaram e enfatizaram a existência destas classificações. Esta tarefa é muito mais complexa do que apenas mudar o nome dos bois.

\section{Referências}

BAUMAN, Z. O mal-estar da pós-modernidade. Rio de Janeiro: Jorge Zahar Editora, 1998.

. Modernidade líquida. Rio de Janeiro: Jorge Zahar Editora, 2001.

BREWIS, J. The making of the competent manager: competency development, Personal Effectiveness and Foucault. Management Learning, special section entitled Critique and Renewal in Management Education, v. 1, n. 27, p. 65-86, 1996.

BREWIS, J. Foucault, politics and organizations: (re)-constructing sexual harassment. Gender, Work and Organization, v. 8, n. 1, p. 37-60, 2001. 
; HAMPTON, M.P.; LINSTEAD, S. Unpacking Priscila: subjectivity and identity in the organization of gendered appearance. Human Relations, v. 50, n. 10, p. 1.275-1.304, 1997.

BREWIS, J.; LINSTEAD, S. The worst thing is the screwing (2): context and career in sex work. Gender, Work and Organization, v. 7, n. 3, p. 168-180, 2000a.

. Sex, work and sex work: eroticizing organization. London: Routledge, $2000 b$.

BUTTON, S. B. Organizational efforts to affirm sexual diversity: a cross-level examination. Journal of Applied Psychology. v. 86, n. 1, p. 17-28, 2001.

CASTELLS, M. O poder da identidade. São Paulo: Paz e Terra, 1999.

CORTINA, L.M.; WASTI, S.A. Profiles in coping: responses to sexual harassment across persons, organizations, and cultures. Journal of Applied Psychology, v. 90, n. 1, p. 182-192, 2005.

COSTA, A.M.M. A discriminação por orientação sexual no trabalho: aspectos legais. In: POCAHY, F. Rompendo o silêncio: homofobia e heterossexismo na sociedade contemporânea. Políticas, teoria e atuação. Porto Alegre: Nuances, 2007.

DELLAGNELO, E.L.; MACHADO-DA-SILVA, C. Literatura sobre novas formas organizacionais: onde se encontram as evidências empíricas de ruptura com o modelo burocrático de organizações? In: ENANPAD, XXV, 2000, Santa Catarina. Anais... Florianópolis, 2000.

ECCEL, C.S.; FLORES-PEREIRA, M.T. A inserção da "diversidade" homossexual em uma livraria de shopping Center: um estudo crítico. In: ENANPAD, 32, 2008, Rio de Janeiro. Trabalhos apresentados. Rio de Janeiro, 2008.

FERREIRA, R.C.; SIQUEIRA, M.V.S. O gay no ambiente de trabalho: análise dos efeitos de ser gay nas organizações contemporâneas. In: ENANPAD, 31, 2007, Rio de Janeiro. Trabalhos apresentados. Rio de Janeiro, 2007.

FOUCAULT, M. Entrevista com Michel Foucault, por Sérgio P. Rouanet e J. G. Merquior. In: FOUCAULT, M. et al. O homem e o discurso: a arqueologia de Michel Foucault. Rio de Janeiro: Edições Tempo Brasileiro, 1996.

. As palavras e as coisas. São Paulo: Martins Fontes, 1999.

. A arqueologia do saber. Rio de Janeiro: Forense Universitária, 2002.

. A ordem do discurso. São Paulo: Edições Loyola, 2003.

GASKA, A.; FREY, D. Occupation-determined role relationships. In: AUHAGEN, A.E.; VON SALISCH, M. The diversity of human relationships. Cambridge: Cambridge University Press, 1996. p. 289-313. 
GREEN, J.N. Além do carnaval: a homossexualidade masculina no Brasil do século XX. São Paulo: UNESP, 2000.

GREENHAUS, J.H.; PARASURAMAN, S.; WORMLEY, W.M. Effects of race on organizational experiences, job performance evaluations, and career outcomes. Academy Of Management Journal, v. 33, p. 64-86, 1990.

GRISCI, C.L.I.; BESSI, V.G. Modos de trabalhar e de ser na reestruturação bancária. Sociologias, v. 6, n. 12, p. 160-200, 2004.

HEBL, M.R. et al. Formal and interpersonal discrimination: a field study of bias toward homosexual applicants. Society for Personality and Social Psychology, v. 28, p. 815-825, 2002.

HEBL, M. R.; GRIFFITH, K. H. The disclosure dilemma for gay men and lesbians: "coming out" at work. Journal of Applied Psychology, v. 87, n. 6, p. 1.191-1.199, 2002.

HEREK, G.M. Stigma, prejudice, and violence against lesbians and gay men. In: GONSIOREK, J.C.; WEINRICH, J.D. Homosexuality: research implications for public policy. Newbury Park, California: Sage, 1991. p. 60-80.

. Psychological perspective on lesbian and gay issues: stigma and sexual orientation. California: Sage, 1998.

IRIGARAY, H.A. Políticas de diversidade nas organizações: uma questão de discurso? In: ENANPAD, 31, 2007, Rio de Janeiro. Trabalhos apresentados. Rio de Janeiro, 2007a.

. A. Estratégia de sobrevivência dos gays no ambiente de trabalho. In: ENANPAD, 31, 2007, Rio de Janeiro. Trabalhos apresentados. Rio de Janeiro, 2007b.

LIM, S.; CORTINA, L.M. Interpersonal mistreatment in the workplace: the interface and impact of general incivility and sexual harassment. Journal of Applied Psychology, v. 90, n. 3, p. 483-496, 2005.

LOURO, G.L. Um corpo estranho: ensaios sobre sexualidade e teoria queer. Belo Horizonte: Autêntica, 2004.

MEDEIROS, M. O trabalhador homossexual: o direito a identidade sexual e a não discriminação no trabalho. In: POCAHY, F. Rompendo o silêncio: homofobia e heterossexismo na sociedade contemporânea. Políticas, teoria e atuação. Porto Alegre: Nuances, 2007.

MEYER, I. H. Minority stress and mental health in gay men. Journal of Health Sciences and Social Behavior, v. 36, p. 38-56, 1995. 
POCAHY, F. Um mundo de injúrias e outras violações. Reflexões sobre a violência heterossexual e homofóbica a partir da experiência do CRDH rompa o silêncio. In: POCAHY, F. Rompendo o silêncio: homofobia e heterossexismo na sociedade contemporânea. Políticas, teoria e atuação. Porto Alegre: Nuances, 2007.

RAGINS, B.R.; CORNWELL, J.M. Pink triangles: antecedents and consequences of perceived workplace discrimination against gay and lesbian employees. Journal of Applied Psychology, v. 86, n. 6, p. 1.244-1.261, 2001.

RIOS, R.R. O conceito de homofobia na perspectiva dos direitos humanos e no contexto dos estudos sobre preconceito e discriminação. In: POCAHY, F. Rompendo o silêncio: homofobia e heterossexismo na sociedade contemporânea. Políticas, teoria e atuação. Porto Alegre: Nuances, 2007.

SCHWARTZ, Y. Os ingredientes da competência: um exercício necessário para uma questão insolúvel. Educação e Sociedade, n. 19, p. 65, 1998.

SIQUEIRA, M.V.S.; FERREIRA, R.C.; ZAULI-FELLOWS, A. Gays no ambiente de trabalho: uma agenda de pesquisa. In: ENANPAD, XXX, 2006, Bahia. Trabalhos Apresentados. Salvador, 2006.

SOUZA, E.M.; GARCIA, A. Amigos, amigos: negócios a parte? In: ENANPAD, XXXI, 2007, Rio de Janeiro. Trabalhos Apresentados. Rio de Janeiro, 2007.

SWAIN, T.N. Para além do binário: os queers e o heterogêneo. Gênero, Niterói, v. 2, n. 1, p. 87-98, 2. sem. 2001.

TRIANDIS, H.C.; KUROWSKI, L.L.; GELFAND, M.J. Workplace diversity. In: TRIANDIS, H.C; DUNNETTE, M.D.; Hough, L.M. Handbook of industrial and organizational psychology. Palo Alto: Consulting Psychologists Press, 1994.

VINCENT, S. Heterofobia e racismo nas organizações. In: CHANLAT, J-F. O indivíduo na organização: dimensões esquecidas. São Paulo: Atlas, 1996.

YANG, A.S. The polls-trends: attitudes toward homosexuality. Public Opinion Quarterly, v. 61, p. 477-507, 1997. 